\title{
Salt stress enhancement of antioxidant and antiviral efficiency of Spirulina platensis
}

\author{
Emad A. Shalaby ${ }^{1 *}$, Sanaa M. M. Shanab² and Vikramjit Singh ${ }^{3}$ \\ ${ }^{1}$ Biochemistry Department, Faculty of Agriculture, Cairo University, Giza, Egypt, 12613, Egypt. \\ ${ }^{2}$ Botany Department, Faculty of Science, Cairo University, Giza, Egypt, 12613, Egypt. \\ ${ }^{3}$ B.Tech in Biotechnology Guru Gobind Singh Indraprastha, University School of Biotechnology, Delhi, India.
}

Accepted 24 July, 2010

\begin{abstract}
Cultivation of Spirulina platensis under salt stress conditions $(0.02 \mathrm{M}$ as control), 0.04 and $0.08 \mathrm{M} \mathrm{NaCl}$ led to a remarkable alteration of algal metabolism as well as an enhancement or induction of biologically active compounds. Concerning algal growth, salt stress caused a decrease in dry weight, chlorophyll a content as well as certain xanthophylls (neoxanthin and violaxanthin) while $\beta$-carotene production was stimulated especially at higher salt concentrations. Biochemical analysis of salt stressed algal revealed that lipid content was slightly increased together with certain saturated and unsaturated fatty acids especially the polyunsaturated ones ( $\gamma$-inolenic acid, omega 3 fatty acid). Electrophoretic analysis of soluble protein pointed out that certain high molecular weight protein bands were not detected comparing with the protein marker. Five new protein bands of molecular weights 190 , $158,113,77$ and $28 \mathrm{KDa}$ were recorded, in addition to an increase in the intensity of 6 already existing bands. Phosphate buffer and water extracts of the algal exhibited antiviral activities against both Hepatitis-A-virus-type-MBB (HAV-MBB strain, RNA virus) and Herpes simplex-virus-type-1 (HSV-1, DNA virus). Water extracts were found to be more effective than phosphate buffer extracts in inducing antiviral activities (98\%) especially against HSV-1 virus. The same water extract of the salt stressed algal demonstrated higher anticoagulating activity compared with those of heparin and the positive control measured by clotting time assay. Antioxidant activity of the algal successive extracts against 2, 2 diphenyl-1-picrylhydrazyl and 2,2'- azino-bis (ethylbenzthiazoline-6- sulfonic acid) radical methods revealed moderate antioxidant activity of the non-polar algal extracts (petroleum ether) which were doubled with increasing extract concentration. The lowest activity was recorded by the partially polar (ethyl acetate) algal extract of both concentrations at all salinity levels. While the polar extracts (ethanol and water) showed higher antioxidant activities which were doubled with increasing extract concentration. Ethanolic algal extract $(100 \mu \mathrm{g} / \mathrm{ml}$ at $0.08 \mathrm{M} \mathrm{NaCl})$ exhibited the highest antioxidant activity compared with those of the synthetic antioxidant butylated hydroxy anisol as standard (85.0, 89.9 and $86.0,91.8 \%$ respectively).
\end{abstract}

Key words: Spirulina platensis, antioxidant-antivirus, biochemical studies, salt stress.

\section{INTRODUCTION}

Many cyanobacteria and micro algae were considered as a natural source of various biologically and pharmacologically active compounds with structurally complex molecules which are difficult or impossible to be

\footnotetext{
*Corresponding author. E-mail: dremad2009@yahoo.com.
}

produced by chemical synthesis (Smith and Doan, 1999). Genus Spirulina has gained an importance and international demand for its high phytonutrients value and pigments which have applications in healthy foods, animal feed, therapeutics and diagnostics (Becker, 1994; Vonshak and Tomaselli, 2000). Spirulina has been used as food and nutritional supplements since long time (Dillon et al., 1995). It is generally a rich source of 
vitamins, essential amino acids, minerals, essential fatty acids such as $y$-linolenic acid and sulfolipid (Mendes et al., 2003). Moreover, in addition to $\omega-3$ and $\omega-6-$ polyunsaturated fatty acids, it has also phytocyanin and other phytochemicals (Chamorro et al., 2002). Some Spirulina species exhibit antibacterial (Ozdemir et al., 2004), antiplatelet (Hsiao et al., 2005), antihepatoxic (Mohan et al., 2006) and antiviral activities (HernandezCorona et al., 2002). Spirulina as many other cyanobacteria species have the potential to produce a large number of antimicrobial substances, so they are considered as suitable candidates for exploitation as biocontrol agents of plant pathogenic bacteria and fungi (Kulik, 1995).

Salinity represents one of the most important factors exerting stress injury on the growth and metabolism of plants. Salt stress causes an imbalance of the cellular ions resulting in ion toxicity and osmotic stress, leading to retardation of growth either directly by salt or indirectly by oxidative stress induced by reactive oxygen species (ROS). Salinity can cause significant accumulation of compatible solutes which acts as enzyme producers, stabilizing the structure of macromolecules and organelles (Dahlich et al., 1983). Salinity stress may alter the metabolic pathways of stressed organism(s) leading to either enhancement or induction of biologically active compounds. The present work aimed to investigate the different biological activities of Spirulina platensis and the relations with its biochemical composition, pigments and different constituents which may vary with salt stressed culture conditions.

\section{MATERIALS AND METHODS}

\section{Chemicals and reagents}

Pure hexane, chloroform, ethanol, ether, acetone, methanol and acetic acid were purchased from E. Merch Co. (Germany), and distilled before use. Butylated hydroxy anisole (BHA), Tween 20, 2, 2 diphenyl-1-picrylhydrazyl (DPPH) and 2,2'- azino-bis (ethylbenzthiazoline-6- sulfonic acid (ABTS), standard fatty acids and hydrocarbons were purchased from Sigma Chemical Company (St. Louis, MO, USA).

\section{Algal species and culture conditions}

S. platensis was obtained from the Laboratory of Phycology, Botany Department, Faculty of Science, Cairo University, Egypt. The algal was cultivated on liquid Zarrouk medium (Zarrouk, 1966). Different sodium chloride concentrations were used ( 0.02 (control), 0.04 and $0.08 \mathrm{M} \mathrm{NaCl}$ ). $S$. platensis was cultured in $3 \mathrm{~L}$ flasks containing $2 \mathrm{~L}$ Zarrouk medium ( $\mathrm{pH}$ 9) containing different salt concentration, 200 $\mathrm{ml}$ algal inocula supplemented with aeration tubes. Cultures were incubated at $25 \pm 1{ }^{\circ} \mathrm{C}$, light intensity of $40 \mu \mathrm{E} / \mathrm{m}^{2} / \mathrm{s}$ (Cool white fluorescent lamps), photoperiod of $16 / 8$ light, dark cycles, for 20 days after which algal cells were harvested by centrifugation at $10,000 \mathrm{rpm} / 5 \mathrm{~min}$, frozen by liquid nitrogen and stored at $-20^{\circ} \mathrm{C}$ till use.

\section{Determination of growth rate by dry weight method}

Algal samples from the different salt concentrations $(10 \mathrm{ml})$ were filtered under vacuum through $0.45 \mu \mathrm{m}$ filter membrane and washed several times with distilled water. Then, algal cells were dried at $100^{\circ} \mathrm{C}$ for $30 \mathrm{~min}$ and weighed (Abd El-Baky et al., 2003).

\section{Phytochemical analysis}

\section{Extraction and determination of algal pigments}

Determination of chlorophyll pigment was carried out according to Holden (1965) method, where the fresh sample $(0.5 \mathrm{~g})$ was grinded in a mortar with acetone in presence of calcium carbonate then filtered. The absorbance of extracts was recorded at 663 and 645 $\mathrm{nm}$ in $1 \mathrm{~cm}$ quartz cell against $80 \%$ aqueous acetone as blank.

\section{Extraction and determination of water soluble pigments (phycobiliprotein)}

The water soluble phycobiliproteins pigments [including allophycocyanin (APC), phycocyanin (PC) and C-phycoerytherine $(\mathrm{C}-\mathrm{PC})]$ were extracted from algal cells $(1 \mathrm{~g})$ with $10 \mathrm{ml}$ phosphate buffer $(0.05 \mathrm{M}, \mathrm{pH} 6.8)$ according to the method described by Bryant (1979). The absorbance (A) of the extracts was recorded at wavelengths 650,620 and $565 \mathrm{~nm}$.

\section{Identification of Spirulina lipophilic pigments by thin layer chromatography (TLC)}

Photosynthetic pigments were separated from $10 \mu \mathrm{l}$ of total lipid extract by silica gel thin layer $\left(60 \mathrm{~F}_{254}\right.$, E.Merck, Germany). The following five solvents systems were used: 1 - Hexane : acetone, (7: $3 \mathrm{v} / \mathrm{v})$; 2- Toluene : acetone, $(6: 4 \mathrm{v} / \mathrm{v})$; 3- Hexane : ether : formic acid, $(80: 20: 2 \mathrm{v} / \mathrm{v} / \mathrm{v}) ; 4$ - Acetone $5 \%$ in chloroform and 5- Petether $\left(40-60^{\circ} \mathrm{C}\right)$ : acetone, $(7: 3 \mathrm{v} / \mathrm{v})$. Identification of individual pigment were determined by $R_{f}$ value on TLC plate which was compared with that of authentic sample and with values reported in literature (Schneider, 1966).

\section{Electrophoretic fractionation of soluble proteins}

Polyacrylamide gel electrophoreses in the presence of Sodium Dodecyl Sulphate (SDS-PAGE) was used for determining the molecular weight of protein fractions (Water soluble protein) according to method of Laemmli (1970). Standard molecular weight proteins marker was obtained from Sigma, this marker contained proteins of different molecular weights: 119 ( $\beta$-galactosidase), 98 (Bovin serum albumin), 52 (Ovalbumin), 36 (Carbonic anhydrase) and 30 (Soybean trypsin inhibitor) KDa.

\section{Extraction and determination of total lipids}

Lipids were extracted by the modified method described by Xu et al. (1998).

\section{Separation and identification of fatty acids}

Fatty acids methyl esters (FAME) were analyzed by gas liquid chromatography (GLC) according to Farag et al. (1986) under specific conditions of column. The separated fatty acids were identified by comparing their retention times with those of standard 
fatty acid methyl ester (purity $99 \%$ by GLC, sigma Co.). Also, Cochromatography and GC/MS methods were used for verification of the peaks identity and position of double bond in fatty acid molecules.

\section{Separation and identification of unsaponified matter}

The unsaponifiable compounds were identified by Gas Liquid Chromatography (GLC) using an instrument equipped with a flame ionization detector (FID). The unsaponifiable compounds (hydrocarbon and sterols) were identified by comparing their retention times with those of standard hydrocarbons from C8 to C36 and some authentic sterols (Cholesterol, stigmasterol and $\beta$ sitosterol).

\section{Biological activities}

\section{Antiviral activity of algal extracts}

Preparation of samples for antiviral bioassay: Extracts were dissolved as $100 \mathrm{mg}$ each in $1 \mathrm{ml}$ of $0.1 \mathrm{M}$ phosphate buffer $(\mathrm{pH} 7)$. The final concentration was $100 \mu \mathrm{g} / \mu \mathrm{l}$ (Stock solution).

\section{Viruses used}

Herpes simplex virus type 1 (HSV-1) and Hepatitis A virus (cell culture adapted strain MBB). The two viruses were obtained from virology laboratory, NRC, Giza, Egypt. Viruses were propagated and titrated on Vero cell (HSV-1) and HepG2 for HAV-MBB strain.

\section{Cytotoxicity assay}

Double fold dilution of each sample was prepared in deionized water (1:2 to 1:256) and diluted samples were inoculated in 96 well. Twice culture plate containing confluent monolayer of Vero cell and another plate containing HepG2 Cells were incubated at $37^{\circ} \mathrm{C}$ overnight and examined microscopically for cytopathic effect (CPE). The lower dilutions, which showed no morphological changes on cell cultures, were selected for antivirus bioassay (Abad et al., 2000).

\section{Plaque infectivity reduction assay}

The method described by Silva et al. (1997) was used where, a 6well plate was cultivated with Vero cell (HSV) and another plate containing HepG2 (HAV) culture $\left(10^{5} \mathrm{cell} / \mathrm{ml}\right)$ and incubated for 2 days at $37^{\circ} \mathrm{C}$. Virus was diluted to give $10^{7} \mathrm{PFU} / \mathrm{ml}$ as final concentrations and mixed with the algal extract at the previous concentration and incubated overnight at $4^{\circ} \mathrm{C}$. Growth medium was removed from the multiwell plate and virus-compound mixture was inoculated $(100 \mu \mathrm{l} / \mathrm{well})$. After contact time, inocula were aspirated, agarose were overlaid, and plates were left to solidify then incubated until the development of virus plaques. Cell sheets were fixed in $10 \%$ formalin and stained with crystal violet stain. Virus plaques were counted and the percentage of reduction was calculated.

\section{Mode of action}

The inhibition mechanism of virus by crude algal extracts was studied using two methods: Viral replication according to Amoros et al. (1994) and viral adsorption according to Zhang et al. (1995).

\section{Determination of anticoagulation activity}

The anticoagulating activities of water algal extracts were investigated using the method of USA pharmacopia (1985) as follow: In each tubes, $0.8 \mathrm{ml}$ of extract solution $(1 \%), 0.8 \mathrm{ml}$ of standard heparin sodium solution (0.5 U.S.P unit/0.8 ml), or $0.8 \mathrm{ml}$ saline solution were added. Then, $1 \mathrm{ml}$ plasma and $0.2 \mathrm{ml}$ of calcium chloride solution (1\%) were added in each tube. The tubes were stopped immediately, and inverted three times to mixed the contents and the entire inner surface of the tube became wet. The time required for clotting was recorded.

\section{Determination of antioxidant activity}

\section{DPPH method}

The 2, 2 diphenyl-1-picrylhydrazyl (DPPH) tests were carried out as described by Burits and Bucar (2000). One $\mathrm{ml}$ of Spirulina extract (Hexane, chloroform, ethyl acetate, ethanol and water extracts) at different concentration was mixed with $1 \mathrm{ml}$ DPPH reagent $(0.002 \%$ (w/v) /methanol water solution). After an incubation period, the absorbance was measured at $517 \mathrm{~nm}$. BHA was used as positive control and extracts concentration providing $50 \%$ inhibition $\left(\mathrm{IC}_{50}\right)$ was calculated from the graph plotting inhibition percentages against extract concentration.

$\%$ Antioxidant activity $=$ Ac-At $/$ Ac $\times 100$

Where At, was the absorbance of the algal extract samples and Ac was the absorbance of methanolic DPPH solution.

\section{ABTS method}

This assay was based on the ability of different substances to scavenge 2,2'- azino-bis (ethylbenzthiazoline-6- sulfonic acid (ABTS . + ) radical cation in comparison to the standard BHA (50 and $100 \mu \mathrm{g} / \mathrm{ml}$ ). According to the method of Re et al. (1999), the antioxidant activity of the tested samples was calculated by determining the decrease in absorbance at different concentrations (50 and $100 \mu \mathrm{g} / \mathrm{ml}$ ) by using the following equation:

$\%$ Antioxidant activity $=((\mathrm{Ac}-\mathrm{At}) / \mathrm{Ac}) \times 100$

Where At, and Ac are the respective absorbance's of tested samples and $\mathrm{ABTS}^{+}$.

\section{Statistical analysis}

Data were subjected to an analysis of variance, and the means were compared using the "Least Significant Difference (LSD)" test at 0.05 and 0.01 levels, as recommended by Snedecor and Cochran (1982).

\section{RESULTS AND DISCUSSION}

Concerning the biochemical analysis of the salt stressed $S$. platensis, the algal growth was slightly affected by low salt concentration $(0.02 \mathrm{M} \mathrm{NaCl})$, increasing salinity $(0.04$ and $0.08 \mathrm{M}$ ) led to a marked and progressive inhibition of growth translated as a decrease in algal dry weight (Figure 1). Our results were in accordance with the results recorded by Fodorpataki and Bartha (2004) where salt stressed (0.5 M) Scenedesmus opoliensis led to an 


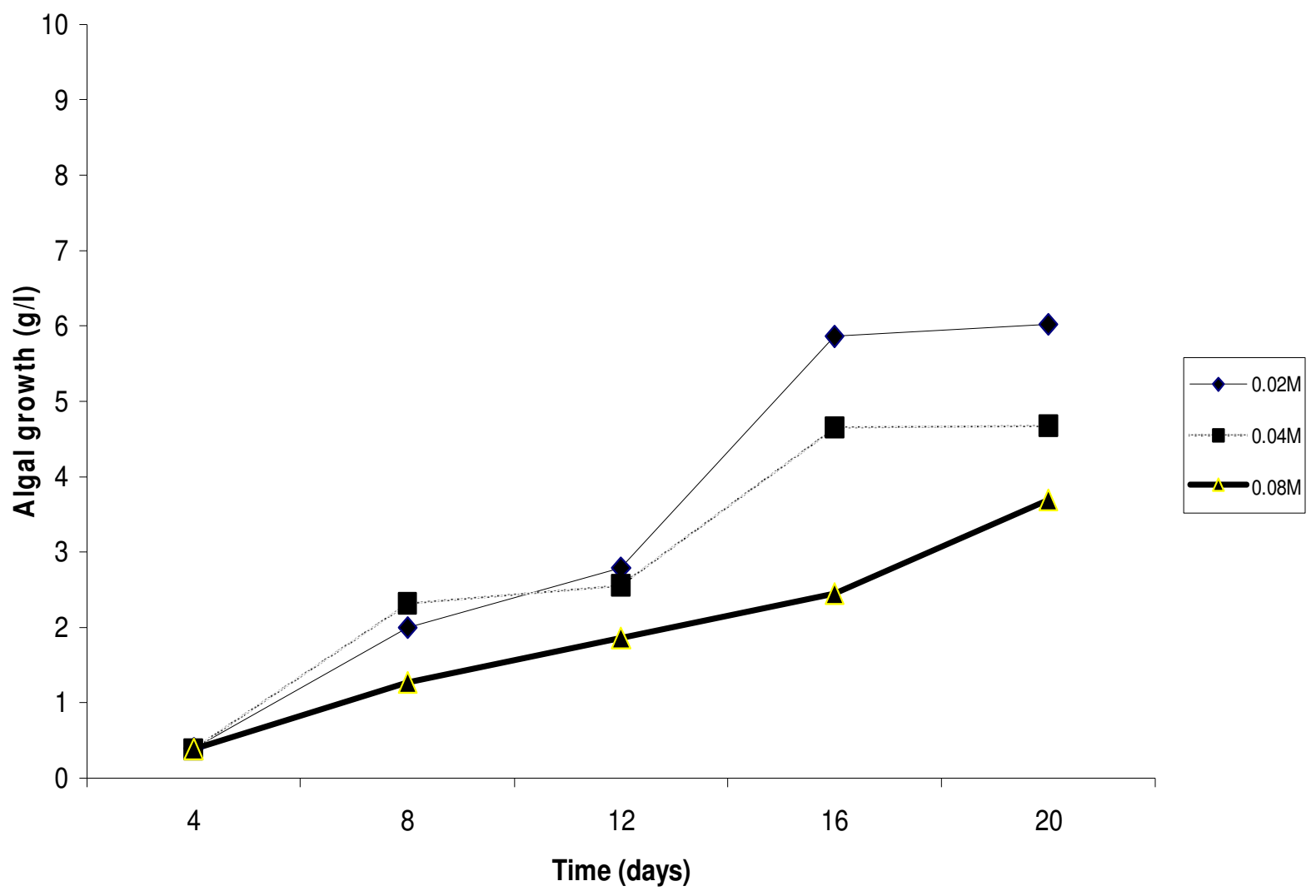

Figure 1. Growth rate of $S$. platensis cultivated under different salt concentration $(0.02,0.04$ and $0.08 \mathrm{M} \mathrm{NaCl})$ during 20 days incubation period, represented as dry weight $(\mathrm{g} / \mathrm{l})$.

Table 1. Separation of $S$. platensis lipid soluble pigments produced under salt stress conditions by TLC using different organic solvent systems.

\begin{tabular}{lllll}
\hline \multirow{2}{*}{ Pigments } & \multirow{2}{*}{$\mathbf{h R}_{\mathbf{f}}$} & \multicolumn{4}{c}{$\mathrm{NaCl}$ concentration (M) } \\
\cline { 2 - 5 } & & $\mathbf{0 . 0 2}$ (control) & $\mathbf{0 . 0 4}$ & $\mathbf{0 . 0 8}$ \\
\hline Myxoxanthophyll & 5.0 & + & + & + \\
Neoxanthin & 10 & + & - & - \\
Violaxanthin & 22 & + & - & - \\
Lutein & 41 & + & + & + \\
Chlorophylla & 67 & + & - & - \\
$\beta$-carotene & 88 & + & + & + \\
\hline
\end{tabular}

${ }^{*}+$ : present -: absent; $h R_{f}: R_{f} \times 100$.

increase in rate of cell divisions, decrease in biomass and chlorophyll content. Sudhir et al. (2005) reported that 0.8 $\mathrm{M} \mathrm{NaCl}$ caused a remarkable decrease in photosystem II (PS II) mediated oxygen evolution activity of $S$. platensis. Our results were in agreement with those of AbdelRahman et al. (2005), who reported that higher salt concentrations $(150-250 \mathrm{mM} \mathrm{NaCl})$ reduced growth, carbohydrate and protein contents of both Chlorella vulgaris and Chlorococcum humicola. Also the obtained results of salt stressed $S$. platensis went parallel with those of Shanab and Galal (2007) where the salt tolerant
Chlorella sp grown under different $\mathrm{NaCl}$ conc (100 - 400 $\mathrm{mM}$ ) their dry weight as well as pigment content were decreased at all $\mathrm{NaCl}$ levels. While the salt sensitive Scenedesmus sp recorded a remarkable decrease in dry weight and pigment content at the lowest salt conc used $(100 \mathrm{mM})$. These results were in concomitant with the obtained results in this investigation.

The inhibition of growth under salt stress conditions was certainly due to alteration of algal metabolism which might be directed towards the production of substances which have a role in algal salt tolerance or defense mechanism. Lipid soluble pigment content (using TLC and Pet-ether $\left(40-60^{\circ} \mathrm{C}\right)$ : acetone, $(7: 3 \mathrm{v} / \mathrm{v})$ as mobile phase) of $S$. platensis (Table 1) was affected by salt stress conditions where chlorophyll a, neoxanthin, violaxanthin were recorded at low salinity and very faintly detected at higher ones while the reverse was shown by $\beta$-carotene. The water soluble phycobiliprotein (Table 2) composed of phycocyanin (CPC), phycoerythrin (PE) and allophycocyanin (APC). Increasing salt conc. enhanced the production of both phycocyanin and phycoerythrin while allophycocyanin (APC) production was inhibited leading to a marked decrease in total phycobiliprotein content. Our results went parallel with those of many investigators (Cifferi, 1983, Piorreck et al., 1984; Becker, 1994 and Rogel-Yogui et al., 2004) where different salt 
Table 2. Relative percent of phycobiliprotein pigments (CPC, APC and PE) of S. platensis cultivated under salt stress conditions (0.02, 0.04 and $0.08 \mathrm{M} \mathrm{NaCl})$.

\begin{tabular}{lcccc}
\hline \multirow{2}{*}{ Concentration of NaCl (M) } & \multicolumn{4}{c}{ Phycobiliprotein pigments (g/100 g F.wt) } \\
\cline { 2 - 5 } & Phycocyanin (CPC) \% & Allophycocyanin (APC)\% & Phycoerytherin (PE)\% & Total phycobilin \% \\
\hline 0.02 (Control) & 1.76 & $5.70^{\mathrm{a}}$ & $0.45^{\mathrm{b}}$ & $7.91^{\mathrm{a}}$ \\
0.04 & 1.80 & $4.50^{\mathrm{b}}$ & $0.65^{\mathrm{a}}$ & $6.95^{\mathrm{b}}$ \\
0.08 & 1.91 & $2.05^{\mathrm{c}}$ & $0.74^{\mathrm{a}}$ & $4.70^{\mathrm{c}}$ \\
LSD & $\mathrm{NS}$ & 0.1006 & 0.1006 & 0.1006 \\
\hline
\end{tabular}

Each value is presented as mean of triplet treatments, means within each row with different letters (a-c) differ significantly at $\mathrm{P} \# 0.05$ according to Duncan's multiple range test.

and nitrogen concentrations induced changes of chlorophyll and phycobiliprotein pigment contents of Spirulina species. It seems that under severe salt stress, the algal defense mechanisms do not allowed to spend too much energy for the synthesis of many new chlorophyll molecules and binding proteins which may explain the decrease in chlorophyll and allophycocyanin contents in our results (Fodorpataki and Bartha, 2004). Moreover, these were confirmed by the absence of protein bands of $47 \mathrm{KDa}$ chlorophyll protein and $94 \mathrm{KDa}$ protein linking phycobilisomes to thylakoid from $S$. platensis SDS-electrophoretic analysis (Garnia et al., 1994; Fodorpataki and Bartha, 2004).

Salt stress conditions not only affected algal growth, pigment content but also protein and lipid production of the stressed alga. Analysis of soluble proteins (by SDS electrophorsis) of $S$. platensis cultivated under different salt concentrations and recorded in Table 3 and Figure 2, revealed that, no protein bands of high molecular weights $(190-117)$, were recorded at the highest $\mathrm{NaCl}$ conc used $(0.08 \mathrm{M})$. While two new highly intensive protein bands of molecular weights 113,77 were recorded only at higher $\mathrm{NaCl}$ conc. Also certain bands were present at low and moderate salt conc $(0.02$ and $0.04 \mathrm{M})$ but absent (not detected) at higher ones $(0.08 \mathrm{M})$. Moreover, six protein bands were detected at low and/or moderate salt conc. but their intensities were highly increased at higher salt stress conditions (of M.wts 106, 90, 82, 67, 35 and 30). Absence of either new protein bands or an increase in the intensity of 42 and $37 \mathrm{KDa}$ bands confirmed the obtained results concerning the decrease in total phycobiliprotein pigments under salt stress conditions. The obtained results concerning protein analysis of salt stressed $S$. platensis was comparable to those of Spirulina maxima cultivated under nitrogen stress condition (Shalaby, 2004). Both Spirulina species have two specific new protein bands of molecular weight 113 and 76 in addition to a highly intensive band at M.wt 103. Higher numbers of new protein bands were recorded in S. maxima at different nitrogen conc. and not equivalent to similar bands (of the same M.wt) produced by $S$. platensis under salinity stress conditions. These differences may be due to variable metabolic processes in both species and to the availability of nitrogen (essential for protein synthesis) in study of $S$. maxima and present only as normal medium constituent in experiments of $S$. platensis.

Concerning lipids of cyanobacteria including Spirulina, they are esters of glycerol and fatty acids; they may be either saturated or unsaturated and may have polyunsaturated fatty acids. Total lipid content of salt stressed S. platensis was slightly increased at higher salt conc. $(8.0,8.0$ and $9.0 \%$ at $0.02,0.04$ and $0.08 \mathrm{M} \mathrm{NaCl}$ respectively). Total lipids contained fatty acids and hydrocarbons which were affected by culture conditions as salinity, N-starvation, light intensity (Tedesco and Duerr, 1989, Abd El-Baky et al., 2004). Generally, exposure of microalgae to any deleterious environmental change responds in many different ways, one of which is the modification of lipid composition in order to maintain the critical degree of membrane fluidity (Romano et al., 2000). The relative percentage of fatty acids in stressed $S$. platensis lipids illustrated in Table 4 recorded remarkable changes which were induced by various salt concentrations. The percentage of total saturated fatty acids produced were 85.6, 37.2 and $67.24 \%$ in $0.02,0.04$ and $0.08 \mathrm{M} \mathrm{NaCl}$ respectively, while the unsaturated fatty acids were 14.9, 62.8 and $32.6 \%$ including $7.2,46.3$ and $14.2 \%$ polyunsaturated fatty acids. These results clearly showed that lipids at lower salt conc. have major percent of saturated fatty acids and as salinity increased (from 0.02 to $0.04 \mathrm{M}$ ) unsaturation also increased including large percentage of polyunsaturated fatty acids (C16:2, C16:3, C18: 2 and C18:3). At higher salt conc. (0.08 M) percent unsaturated fatty acids decreased due to the desaturation, oxidative peroxidation and consequently changes in membrane fluidity, permeability and cellular metabolic functions (Bandopadhyay et al., 1999, Singh et al., 2002). Relative percentage of hydrocarbons was also affected by salinity stress where $\mathrm{C} 12, \mathrm{C} 15$ and $\mathrm{C} 36$ were not detected at all $\mathrm{NaCl}$ conc while $\mathrm{C} 18$ was only produced with moderate percentage at $0.04 \mathrm{M}$ then markedly decreased at higher salinity level. C20 was only recorded at lower salt conc. on the other hand C21, C22, C26, C28, C29 and C30 were present at all salinity levels but with different relative percentages, C21 was highly 
Table 3. SDS-Electrophoretic analysis of soluble proteins produced by the salt stressed S. platensis cultivated under different $\mathrm{NaCl}$ Concentration $(0.02,0.04$ and $0.08 \mathrm{M})$.

\begin{tabular}{|c|c|c|c|c|c|}
\hline \multirow{2}{*}{$\begin{array}{l}\text { Protein } \\
\text { band }\end{array}$} & \multirow{2}{*}{ Molecular weight (kDa) } & \multirow{2}{*}{$\mathbf{h} \mathbf{R}_{\mathbf{f}}$} & \multicolumn{3}{|c|}{ Concentration of $\mathrm{NaCl}(\mathrm{M})$} \\
\hline & & & 0.02 (Control) & 0.04 & 0.08 \\
\hline \multicolumn{6}{|c|}{ High molecular weight (HMW, \%) } \\
\hline $1^{*}$ n.p & 190 & 0.7 & - & 5.99 & - \\
\hline 2 & 180 & 2.1 & 4.1 & - & - \\
\hline 3 & 167 & 8.1 & 1.4 & 2.72 & - \\
\hline 4 & 160 & 10.2 & 3.45 & 3.09 & - \\
\hline $5^{*}$ n.p & 158 & 10.8 & - & 0.73 & - \\
\hline 6 & 150 & 13.3 & 1.32 & 1.55 & - \\
\hline 7 & 147 & 14.3 & 2.4 & - & - \\
\hline 8 & 145 & 15.7 & 3.0 & 2.65 & - \\
\hline 9 & 137 & 18.8 & 2.94 & 2.15 & - \\
\hline 10 & 133 & 20.9 & 1.2 & 2.60 & - \\
\hline 11 & 124 & 24.3 & 4.56 & 3.79 & - \\
\hline 12 & 117 & 27.8 & 5.6 & 4.31 & - \\
\hline $13^{*} n \cdot p$ & 113 & 28.8 & - & - & 8.62 \\
\hline 14 & 106 & 31.8 & 2.23 & 2.32 & 5.53 \\
\hline 15 & 103 & 33.3 & 1.32 & - & 12.14 \\
\hline 16 & 101 & 34.3 & 2.2 & - & - \\
\hline \multicolumn{6}{|c|}{ Medium molecular weight (MMW, \%) } \\
\hline 17 & 97 & 35.9 & 2.25 & 3.23 & - \\
\hline 18 & 93 & 37.3 & 1.36 & 3.28 & - \\
\hline 19 & 90 & 39.1 & 2.30 & 1.60 & 14.05 \\
\hline 20 & 89 & 39.9 & 2.9 & 3.94 & - \\
\hline 21 & 82 & 43.1 & 4.19 & 4.16 & 11.98 \\
\hline $22^{*}$ n.p & 77 & 46.8 & - & - & 8.96 \\
\hline 23 & 73 & 48.7 & 4.48 & 4.32 & - \\
\hline 24 & 67 & 52.3 & 1.06 & 3.34 & 13.47 \\
\hline 25 & 64 & 53.1 & 0.36 & 4.94 & - \\
\hline 26 & 58 & 57.8 & 5.64 & 5.65 & - \\
\hline 27 & 50 & 60.5 & 4.5 & 3.41 & - \\
\hline \multicolumn{6}{|c|}{ Low molecular weight (LMW, \%) } \\
\hline 29 & 47 & 65.4 & 5.3 & 3.53 & - \\
\hline 30 & 40 & 71.3 & 2.88 & 4.36 & - \\
\hline 31 & 38 & 77 & 3.77 & 8.00 & 8.08 \\
\hline 32 & 35 & 81 & 2.64 & 5.34 & 6.53 \\
\hline 33 & 30 & 82.3 & 10.23 & 3.68 & 10.64 \\
\hline $34^{*}$ n.p & 28 & 86.7 & - & 1.84 & - \\
\hline 35 & 25 & 90.2 & 5.78 & 3.48 & - \\
\hline
\end{tabular}

*: not present; n.p: new protein; $h R_{f}: R_{f} \times 100$.

increased at moderate salinity conc (53.7\%) then dropped to $2.5 \%$ at high salt conc, while C22 was markedly increased at higher $\mathrm{NaCl}$ conc. (28.3\%). Also $\mathrm{C} 29$ has relative percent at low $\mathrm{NaCl}$ conc. $(22.3 \%)$ which was doubled at higher salt stress condition to reach 43.9\%. C32 was markedly decreased with increasing $\mathrm{NaCl}$ concentration from 0.02 to $0.04(18,1.2 \%)$ then completely disappeared at higher salinity level. The obtained biochemical analysis of $S$. platensis encouraged the investigation of various biological activities.

Concerning the antiviral activity, Table 5 showed that algal water extract $(50 \mu \mathrm{g} / \mathrm{ml})$ of low salt concentration $(0.02 \mathrm{M})$ exhibited relatively higher $(60.0 \%)$ antihepatitis A virus-type MBB more than phosphate buffer extract 


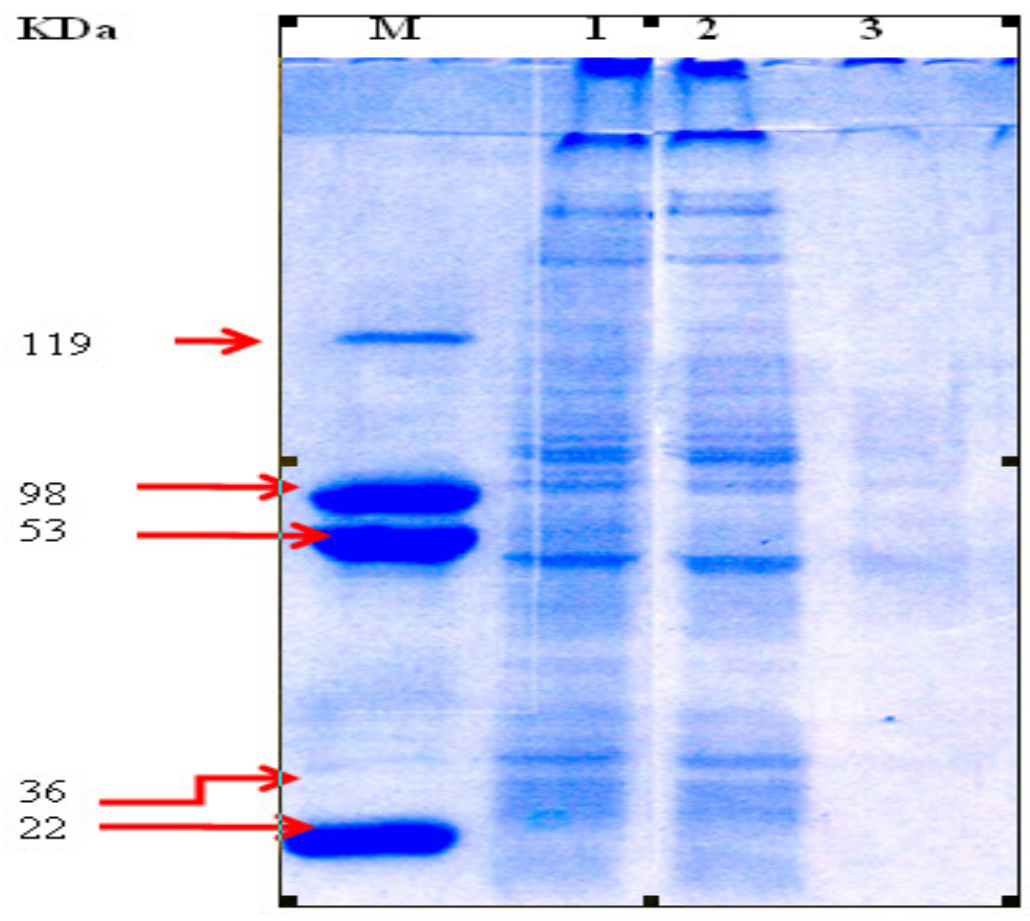

Figure 2. SDS-Electrophoretic analysis of soluble proteins produced by the salt stressed $S$.platensis cultivated under different $\mathrm{NaCl}$ Concentration $(0.02,0.04$ and $0.08 \mathrm{M})$.

Table 4. Relative percentage (\%) of fatty acids and hydrocarbons in S. platensis lipid extract produced under different $\mathrm{NaCl}$ concentrations $(0.02,0.04$ and $0.08 \mathrm{M})$.

\begin{tabular}{|c|c|c|c|c|c|c|c|}
\hline \multirow{2}{*}{ Fatty acids } & \multicolumn{3}{|c|}{ Sodium chloride conc. (M) } & \multirow{2}{*}{ Hydrocarbons } & \multicolumn{3}{|c|}{ Sodium chloride conc. (M) } \\
\hline & 0.02 & 0.04 & 0.08 & & 0.02 & 0.04 & 0.08 \\
\hline C8:0 & 0.4 & 0.2 & 0.24 & $\mathrm{C} 12$ & - & - & - \\
\hline C10:0 & - & - & - & C15 & - & - & - \\
\hline C12:0 & 0.4 & 1.3 & 4.2 & C18 & - & 19.7 & 0.5 \\
\hline C14:0 & 10.5 & - & 10.5 & $\mathrm{C} 20$ & 11.3 & - & - \\
\hline C16:0 & 29.8 & 18.0 & 25.2 & C21 & 0.8 & 53.7 & 2.5 \\
\hline$C 16: 1(\omega 7)$ & 2.9 & 5.5 & 3.6 & $\mathrm{C} 22$ & 2.8 & 1.9 & 28.3 \\
\hline $\mathrm{C} 16: 2(\omega 2)$ & 2.7 & 2.3 & 5.9 & $\mathrm{C} 26$ & 19.0 & 2.9 & 2.9 \\
\hline $\mathrm{C} 16: 3(\omega \mathrm{s})$ & 2.9 & 22.5 & 6.6 & $\mathrm{C} 28$ & 13.6 & 15.2 & 12.3 \\
\hline C17:0 & - & - & - & C29 & 22.3 & 3.7 & 43.9 \\
\hline C18:0 & 44.5 & 17.7 & 27.1 & C30 & 11.1 & 1.7 & 9.5 \\
\hline C18:1 (w 9) & 2.8 & 11.0 & 15.8 & C32 & 18.0 & 1.2 & - \\
\hline $\mathrm{C} 18: 2(\varphi 6)$ & 2.0 & 7.4 & - & C34 & 1.0 & - & - \\
\hline $\mathrm{yC18:3( \omega 6)}$ & 1.6 & 14.1 & 0.7 & C36 & - & - & - \\
\hline Total saturated acids & 85.6 & 37.2 & 67.24 & & & & \\
\hline Total monounsaturated fatty acids & 5.7 & 16.5 & 19.4 & & & & \\
\hline Total polyunsaturated fatty acids & 9.2 & 46.3 & 13.2 & & & & \\
\hline Total omega 6 fatty acids & 3.6 & 21.5 & 0.7 & & & & \\
\hline Total omega 3 fatty acids & 2.9 & 22.5 & 6.6 & & & & \\
\hline Total lipids (\%) & $8.0 \pm 0.4$ & $8.0 \pm 0.2$ & $9.0 \pm 0.6$ & & & & \\
\hline $\mathrm{TU} / \mathrm{Ts}$ & 0.17 & 1.6 & 0.48 & & & & \\
\hline
\end{tabular}

*Each value represents the average of three replicate run.TU/TS: Total unsaturated/Total Saturated, *- : not present. 
Table 5. Antiviral activity (\%) of phosphate buffer and water extracts of the salt stressed S. platensis (at conc.20 and 50 $\mu \mathrm{g} / \mathrm{ml}$ ) using Hepatitis A virus type MBB (HAV-MBB) and Herpes Simplex virus type 1 (HSV-1).

\begin{tabular}{|c|c|c|c|c|c|c|c|c|}
\hline \multirow{3}{*}{$\mathrm{NaCl}(\mathrm{M})$} & \multicolumn{4}{|c|}{ HAV-MBB virus (RNA virus) } & \multicolumn{4}{|c|}{ HSV-1 virus (DNA virus) } \\
\hline & \multicolumn{2}{|c|}{$20 \mu \mathrm{g} / \mathrm{ml}$} & \multicolumn{2}{|c|}{$50 \mu \mathrm{g} / \mathrm{ml}$} & \multicolumn{2}{|c|}{$20 \mu \mathrm{g} / \mathrm{ml}$} & \multicolumn{2}{|c|}{$50 \mu \mathrm{g} / \mathrm{ml}$} \\
\hline & $\begin{array}{c}\text { Phosphate } \\
\text { buffer }\end{array}$ & $\begin{array}{l}\text { Water } \\
\text { extract }\end{array}$ & $\begin{array}{c}\text { Phosphate } \\
\text { buffer }\end{array}$ & $\begin{array}{l}\text { Water } \\
\text { extract }\end{array}$ & $\begin{array}{c}\text { Phosphate } \\
\text { buffer }\end{array}$ & $\begin{array}{l}\text { Water } \\
\text { extract }\end{array}$ & $\begin{array}{c}\text { Phosphate } \\
\text { buffer }\end{array}$ & $\begin{array}{l}\text { Water } \\
\text { extract }\end{array}$ \\
\hline 0.02 (Control) & $9.0^{c}$ & $40.0^{a}$ & $9.0^{c}$ & $60.0^{\mathrm{a}}$ & 90.0 & $96.0^{\mathrm{a}}$ & $93.0^{\mathrm{b}}$ & $98.0^{\mathrm{a}}$ \\
\hline 0.04 & $56.0^{\mathrm{a}}$ & $32.0^{\mathrm{b}}$ & $58.0^{\mathrm{a}}$ & $34.0^{\mathrm{b}}$ & 88.0 & $90.0^{\mathrm{b}}$ & $90.0^{\mathrm{C}}$ & $94.0^{b}$ \\
\hline 0.08 & $32.0^{\mathrm{b}}$ & $25.0^{\mathrm{C}}$ & $37.0^{\mathrm{b}}$ & $25.0^{\mathrm{C}}$ & 90.0 & $96.0^{\mathrm{a}}$ & $98.0^{\mathrm{a}}$ & $98.0^{\mathrm{a}}$ \\
\hline LSD & 2.0318 & 1.1006 & 2.465 & 2.465 & NS & 1.123 & 2.250 & 2.250 \\
\hline
\end{tabular}

Each value is presented as mean of triplet treatments, means within each with different letters (a-c) differ significantly at $P \neq 0.05$ according to Duncan's multiple range test.

$(9.0 \%)$ of the same concentration and the activity of the latter extract increased (56.0 - 58.0\%) at moderate salt concentration $(0.04 \mathrm{M})$ using 20 and $50 \mu \mathrm{g} / \mathrm{ml}$ extract concentration respectively. On the other hand, the antiviral activity against herpes simplex virus -type 1 showed a comparable activity by both water and phosphate buffer extracts of both concentrations at all salinity levels with maximum antiviral activity $(98.0 \%)$ at $50 \mathrm{ug} / \mathrm{ml}$ extract concentration. The antiviral activity against HSV-1 (DNA virus) was markedly pronounced $(98.0 \%)$ than that against HAV-MBB $(60.0 \%)$ which is RNA virus. These activities which were shown to be controlled by both type and concentration of algal extract (water or phosphate buffer, at 20 and $50 \mu \mathrm{g} / \mathrm{ml}$ ) may be induced by the sulphated polysaccharide and tannins in S. platensis extracts (Witvrouw and De Clereq, 1997). These antivirus substances may interfere at one or more of viral stages, either at the stage of virus attachment or penetration to the host cell, or at the virus replication or the virus maturity and release stages. The obtained results concerning these activities against HAV-MBB and HSV-1 viruses were in agreement with the data obtained by Hayashi et al. (1996) who found that water extract of $S$. platensis inhibited the replication in vitro of herpes simplex virus type 1 in Hela cell within the concentration range $80-50 \mu \mathrm{g} / \mathrm{ml}$. our results were also in accordance with those reported by Witvrouw and De Clercq (1997), who emphasized that sulphated polysaccharides were found to be potent and selective inhibitors of HIV-1 replication in cell culture. Moreover, Ayehunine et al. (1998) reported that an aqueous extract of $S$. platensis inhibited HIV-1 replication in human T-cell lines and langerhans cells and their antiviral activity was found in polysaccharides fraction. Our results were confirmed by and coincided with the results reported by Shalaby (2004), where phosphate buffer and water extracts of $S$. maxima cultivated under different $\mathrm{N}$-conc. exhibited weak antiviral activity against HAV-MBB and highly pronounced activity against HSV-1 viruses. He added that the sulphated polysaccharides produced from the fractionation of water extract called (Ca-Spirulina) caused the inhibition of virus penetration into the host cells.
Experiments carried out with dextran sulphate revealed that the antiviral activity increased with increasing molecular weight and degree of sulfation of the sulphated polysaccharides. Many microalgal polysaccharides significantly inhibit the infection of Vero cell by HSV-1, HSV-2 and VZV viruses, and these compounds did not show any cytotoxic effects even at greater dose concentration (Huleih et al., 2001).

The activity of polar extract of $S$. platensis at (concentration of 20 and $50 \mu \mathrm{g} / \mathrm{ml}$ ) against HSV-1 and the clinical strain were evaluated by the plaque reduction assay. the algal extract did not induce any effect on virus replication The effect of algal extract on virus adsorption in the second set of experiment, the inhibitory effect of extract of Spirulina sp at (concentration of 20 and 50 $\mu \mathrm{g} / \mathrm{ml}$ ) on virus adsorption to host cell was measured by monitoring the attachment of infectious HSV virions on host cells in the presence of their extract. The results indicated that algal extracts completely inhibited (99.99\%) the cell-associated infectivity as compared with that in control levels. These results were in agreement with those obtained by Boyed et al. (1997) who found that the antiviral activity of cyanovirin- $\mathrm{N}(\mathrm{CV}-\mathrm{N})$ isolated from Nostoc sp against HIV-2 is due, at least in part, to unique, high-affinity interaction of CV-N with the viral surface envelope (glycoprotein gp120).

The mode of action of $S$. platensis extracts at (concentration of 20 and $50 \mu \mathrm{g} / \mathrm{ml}$ ) against both viruses were evaluated by the plaque reduction assay. The results reported that the micro algal extract did not induce any effect on virus replication but completely inhibited $(100 \%)$ the cell-associated infectivity as compared with that in control levels.

Regarding the anticoagulation activity of the hot water extract of salt stressed $S$. platensis, the obtained results (Figure 3) showed that great anticoagulating efficiency (expressed by clotting time assay) compared with that of the standard anticoagulatant heparin (sulfate glucouronic acid) to be 13 and $17 \mathrm{~min}$. respectively. our results were in agreement with those recorded by Shalaby (2004) on $S$. maxima where the clotting times were inversely proportional to nitrate concentration in the growth media 


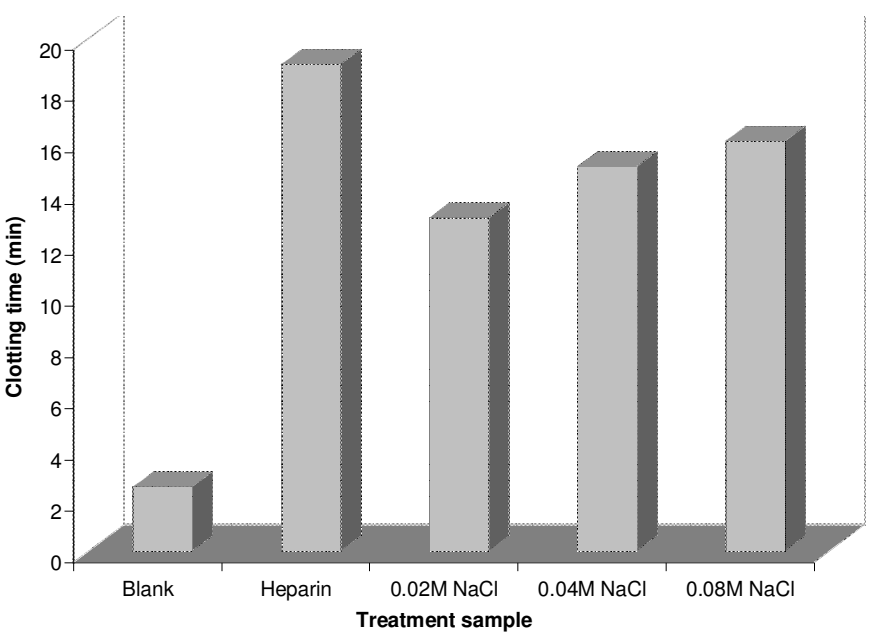

Figure 3. Anticoagulation activity (clotting time) of the hot water extracts of the salt stressed S. platensis.

Table 6. Antioxidant activity (\%) of salt stressed S. platensis using different solvent extracts (pet. ether, ethyl acetate, ethanol and water) of different concentration (50 and $100 \mu \mathrm{g} / \mathrm{ml}$ ), butylated hydroxyl anisole (BHA) was used as standard antioxidant against DPPH radical.

\begin{tabular}{clcc}
\hline \multirow{2}{*}{$\mathrm{NaCl}(\mathrm{M})$} & \multirow{2}{*}{ Solvent extract } & \multicolumn{2}{c}{ Concentration $(\boldsymbol{\mu g} / \mathbf{m l})$} \\
\cline { 3 - 4 } & & $\mathbf{5 0}$ & $\mathbf{1 0 0}$ \\
\hline 0.02 (Control) & Pet.ether (40-60) & $29.0 \pm 2.3^{\mathrm{m}}$ & $55.0 \pm 3.2^{\mathrm{f}}$ \\
& Ethyl acetate & $0.0 \pm 0.0^{\mathrm{u}}$ & $9.0 \pm 0.5^{\mathrm{s}}$ \\
& Ethanol & $31.5 \pm 1.5^{\mathrm{k}}$ & $75.0 \pm 3.8^{\mathrm{b}}$ \\
& Water & $30.0 \pm 2.4^{\mathrm{l}}$ & $65.0 \pm 2.6^{\mathrm{d}}$ \\
& & & \\
0.04 & Pet.ether (40-60) & $29.0 \pm 0.8^{\mathrm{m}}$ & $62.3 \pm 2.8^{\mathrm{e}}$ \\
& Ethyl acetate & $0.0 \pm 0.0^{\mathrm{u}}$ & $11.0 \pm 0.9^{\mathrm{r}}$ \\
& Ethanol & $20.5 \pm 2.5^{\mathrm{o}}$ & $44.0 \pm 4.5^{\mathrm{h}}$ \\
& Water & $20.0 \pm 1.6^{\mathrm{p}}$ & $45.0 \pm 3.5^{\mathrm{g}}$ \\
0.08 & Pet.ether (40-60) & $11.0 \pm 0.1^{\mathrm{r}}$ & $25.0 \pm 0.89^{\mathrm{n}}$ \\
& Ethyl acetate & $5.0 \pm 0.6^{\mathrm{t}}$ & $17.0 \pm 1.0^{\mathrm{q}}$ \\
& Ethanol & $32.0 \pm 2.8^{\mathrm{j}}$ & $85.0 \pm 4.8^{\mathrm{a}}$ \\
& Water & $35.6 \pm 4.3^{\mathrm{i}}$ & $65.8 \pm 3.8^{\mathrm{c}}$ \\
& & & \\
BHA & & $60.6 \pm 2.6^{\mathrm{e}}$ & $86.5 \pm 4.5^{\mathrm{a}}$ \\
LSD & & 0.9179 & \\
\hline
\end{tabular}

Each value is presented as mean of triplet treatments, means within each row with different letters (a-s) differ significantly at $P \neq 0.05$ according to Duncan's multiple range test.

(11, 12, 13 at 410, 205, 102.5 ppm N compared with 16 min in case of heparin). This activity was reported to have a close relation with the water extract containing sulfated polysaccharides and phenolic compounds and depend upon the molecular size, type of sugar, sulphate content and position of the active components (Shanmugam
Table 7. Antioxidant activity (\%) of salt stressed S. platensis using different solvent extracts (pet. ether, ethyl acetate, ethanol and water) of different concentration (50 and $100 \mu \mathrm{g} / \mathrm{ml}$ ), butylated hydroxyl anisole (BHA) was used as standard antioxidant against ABTS radical.

\begin{tabular}{llcc}
\hline $\mathrm{NaCl}(\mathrm{M})$ & Solvent extract & \multicolumn{2}{c}{ Concentration $(\boldsymbol{\mu \mathrm { g } / \mathrm { ml } )}$} \\
\hline & & $\mathbf{5 0}$ & $\mathbf{1 0 0}$ \\
\hline \multirow{3}{*}{0.02 (control) } & Pet.ether (40-60) & $28.4 \pm 1.5^{\mathrm{jk}}$ & $60.4 \pm 4.1^{\mathrm{e}}$ \\
& Ethyl acetate & $5.6 \pm 0.5^{\mathrm{p}}$ & $9.4 \pm 1.0^{\circ}$ \\
& Ethanol & $34.8 \pm 1.0^{\mathrm{i}}$ & $81.7 \pm 3.5^{\mathrm{b}}$ \\
& Water & $32.5 \pm 2.6^{\mathrm{i}}$ & $64.8 \pm 2.4^{\mathrm{d}}$ \\
& & & \\
& Pet.ether (40-60) & $29.9 \pm 3.4^{\mathrm{ij}}$ & $66.8 \pm 3.6^{\mathrm{cd}}$ \\
0.04 & Ethyl acetate & $6.8 \pm 0.5^{\mathrm{op}}$ & $16.5 \pm 2.3^{\mathrm{m}}$ \\
& Ethanol & $22.4 \pm 0.3^{\mathrm{l}}$ & $45.8 \pm 1.8^{\mathrm{g}}$ \\
& Water & $26.5 \pm 1.2^{\mathrm{k}}$ & $50.8 \pm 5.0^{\mathrm{f}}$ \\
& & & \\
& Pet.ether (40-60) & $12.3 \pm 0.08^{\mathrm{n}}$ & $26.8 \pm 1.3^{\mathrm{k}}$ \\
0.08 & Ethyl acetate & $8.9 \pm 2.0^{\circ}$ & $23.6 \pm 2.4^{\mathrm{a}}$ \\
& Ethanol & $40.8 \pm 1.2^{\mathrm{h}}$ & $89.9 \pm 5.6^{\mathrm{a}}$ \\
& Water & $40.5 \pm 3.0^{\mathrm{h}}$ & $68.9 \pm 3.1^{\mathrm{c}}$ \\
BHA & & & \\
LSD & & $67.4 \pm 2.3^{\mathrm{d}}$ & $91.8 \pm 4.5^{\mathrm{a}}$ \\
\hline
\end{tabular}

Each value is presented as mean of triplet treatments, means within each row with different letters $(a-p)$ differ significantly at $P \neq 0.05$ according to Duncan's multiple range test.

and Mody, 2000). Therefore, in future, algal sulphated polysaccharides water extracts can be used as anticoagulant/antithrombitic agent, in medical purposes, replacing the known heparin which was extracted from internal organs of higher animals and exhibited haemorrhagic like side effects.

Extracts of $S$. platensis by organic solvents of different polarities and concentrations showed that the polar solvents (ethanol and water) extracts at higher concentration $(100 \mu \mathrm{g} / \mathrm{ml})$ exhibited higher antioxidant activity $(85.0$ and $89.9 \%$ by DPPH and ABTS respectively) comparable to the standard antioxidant, BHA ( 86.5 and $91.8 \%)$. This is followed in the second order by the non-polar (pet. ether) extract at high concentration $(100 \mu \mathrm{g} / \mathrm{ml})$ of both low $(0.02 \mathrm{M})$ and moderate $(0.04 \mathrm{M})$ salinity levels $(55.0,62.3,60.4$, and $66.8 \%$ by DPPH and ABTS respectively) while the partially polar (ethyl acetate) extracts demonstrated the lowest antioxidant activities at all salt concentrations (ranged from 0.0 to $23.6 \%$ ) as recorded in Tables 6 and 7.

The obtained results revealed that polar antioxidant substances might be present in the polar Spirulina extract to which attributed the antioxidant activity. These polar substances were found in extracts of different red, brown and green seaweeds (Matsukawa et al., 1997; Anggediredja et al., 1997; Lim et al., 2002; Santoso et al., 
2004; Zhang et al., 2007; Shanab, 2007; Shalaby, 2008) as well as in micro algae and cyanobacterial species (Abd El-Baky, 2003; Reddy et al., 2003; Benedetti et al., 2004; Shalaby, 2004) these substances mainly include phycocyanin pigment, sulphated polysaccharides and phenolic compounds which are largely present in most macro, micro and cyanobacterial species which exhibited pronounced antioxidant activity. Non-polar antioxidant substances were recorded also in microalgae as Chlorella vulgaris, Dunaliella salina (Nirupama, 2004; Murthy et al., 2005; Zhang-Bao et al., 2004) in cyanobacteria (Shalaby, 2004) in addition to the different seaweed species (Krinsky, 1989; Hyun et al., 2003; Xi et al., 2003; Sook et al., 2004; Yuan et al., 2005; Shanab, 2007; Shalaby, 2008). These non-polar substances include carotenoids ( $\beta$-carotene, Astaxanthin, and Zeaxanthin), chlorophylls and fatty acids which were largely enhanced by salinity stress and reported to have higher antioxidant activities (Endo et al., 1985; Murthy et al., 2005).

\section{REFERENCES}

Abad MJ, Guerra JA, Bermerjo P, Irurzun A, Carrasco L (2000). Search for antiviral activity in higher plant extracts. Phytother. Res., 14: 604607.

Abd El-Baky, HH (2003). Over production of phycocyanin pigments in blue green alga Spirulina sp. and its inhibitory effect on growth of Ehrlich Ascites Carcinoma Cells. J. Med. Sci., 3: 314-324.

Abd El-Baky HH, El Baz FK, El-Baroty GS (2003). Spirulina species as a source of carotenoids and $\alpha$-tocopherol and its anticarcinoma factors. Biotechnology, 2: 222-240.

Abd El-Baky HH, El Baz FK, El-Baroty GS (2004). Production of antioxidant by the green alga Dunaliella salina Int. J. Agric. Biol., 1: 49-57.

Abdel-Rahman MHM, Ali RM, Said HA (2005). Alleviation of $\mathrm{NaCl}$ induced effects on Chlorella vulgaris and Chlorococcum hunmicola by riboflavin application. Int. J. Agric. Biol., 7(1): 58-62.

Amoros M, Lurton E, Boustie J, Girre L(1994). Comparison of the antiherpes simplex virus activities of propolis and 3- methyl-But-2-Enyl cafferate. J. Nat. Prod., 57(5): 644-647.

Anggediredja J, Andyani R, Hayati, Muawanah H (1997). Antioxidant activity of Sargassum polycystum (Phaeophyta) and Laurancia obtusa (Rhodophyta) from Seribu Islands. J. Appl. Phycol., 9: 477479.

Ayehunine S, Belay A, Baba TW, Ruprechi RM (1998). Inhibition of HIV1 replication by an aqueous extract of Spirulina platensis (Arthrospira platensis). J. Acquir. Immune Defic. Syndr. Hum. Retrovirol., 18: 712.

Bandopadhyay U, Das D, Danerjee RK (1999). Reactive oxygen species: Oxidative damage and pathogenesis. Curr. Sci., 77: 658666.

Becker EW (1994). Microalgae. Cambridge Univ. Press. Cambridge, New York.

Benedetti S, Benevenuti F, Pagliarani S, Francogli, S, Scoglio S Cansestrari $F$ (2004). Antioxidant properties of a novel phycocyanin extract from the blue-green alga Aphanizomenon flos-aqae.Life-Sci., 75(19): 2353-2362.

Boyed PW, Pomroy A, Bury S, Savidge G, Joint I (1997). Micro-algal carbon and nitrogen uptake in post-coccolithophore bloom conditions in the NE Atlantic, July 1991. Deep-Sea Res.,1(44): 1497-1517.

Bryant DA (1979). Phycoerythrin and phycocyanin properties and occurance in cyanobacteria. J. Gen. Microbiol., 128: 835-844.

Burits M, Bucar F (2000). Antioxidant activity of Nigella Sativa essential oil . Phytother. Res., 14: 323-328.

Chamorro G, Salazer M, Araujo KG, deo Santos CP, Ceballos G,
Castillo LF (2002). Update on the pharmacology of Spirulina (Arthrospira), A conventional food. Arch. Latinoam Nutr., 52: 232-40.

Cifferi, O. (1983). Spirulina, the edible microorganism. Microbiol. Rev., 47: 551.

Dahlich E, Kerres R, Jager HJ (1983). Influence of water stress on vacuole/extravacuola distribution of praline in protoplasts of Nicotiana rustica. Plant Physiol., 72: 590-591.

Dillon JC, Phuc AP, Dubacq JP (1995). Nutritional value of the algae Spirulina.World Rev. Nutr. Diet, 77: 32-46.

Endo Y, Usuki R, Kaneda T (1985). Antioxidant effects of chlorophyll and phaeophytin on the autoxidation of oils in the dark-II the mechanism of antioxidative action of chlorophyll. J. Am. Oil. Chem. Soc., 62: 1387-1390.

Farag RS, Hallaba SA, Hewedi FE, Basyony AE (1986). Chemical evaluation of rapeseed. Fette Seifen Antrichmittel, 88: 391-397.

Fodorpataki L, Bartha C (2004). Salt stress tolerance of a freshwater green alga under different photon flux densities. Sludia Universities Babes-Bolyai, Biologia, XLIX, 2: 85-93.

Garnia F, Dubacq JP, Thomas JC (1994). Evidence for a transient association of new proteins with the Spirulina maxima phycobilisomes in relation to light intensity. Plant Physiol., 106: 747754.

Hayashi K, Hayashi T, Kojima I (1996). A natural sulfated polysaccharide, calcium Spirulina, isolated from Spirulina platensis: in vitro and ex vivo evaluation of anti herpes simplex virus and antihuman immunodeficiency virus activities. AIDS Res. Hum. Retroviruses, 12(15): 1463-1471.

Hernandez-Corona A, Nieves I, Meckes M, Chamorro G, Barron BI (2002). Antiviral activity of Spirulina maxima against Herpes simplex virus type2. Antiviral Res., 56(3): 279-285.

Holden M (1965). Chlorophyll - In chemistry and biochemistry of plant pigments. Ed. Goodwin, TW., Academic Press, London, pp. 462-488.

Hsiao G, Chou PH, Shen MY, Chou DS, Lin Ch, Cheu JR (2005). CPhycocyanin,a very potent and novel platelet aggregation inhibitor from Spirulina platensis. J. Agric. Food Chem., 53(20): 7734-7740.

Huleih M, Ishanu V, Tal J, Arad S (2001). Antiviral effect of red microalgal polysaccharides on Herps simplex and Varicella zoster viruses. J. Appl. Phycol., 13:127-134.

Hyun L-S, Sil LY, Hoon JS, Sik KS, Hyun SK (2003).Antioxidant activities of fucosterol from the marine alga Pelvetia Siliquosa. Arch. Pharmacol. Res., 26(9): 719-722.

Krinsky NI (1989). Antioxidant functions of carotenoids. Free Radic. Biol. Med., 7(6): 617-635

Kulik MM(1995). The potential for using cyanobacteria (blue green algae) and in the biological control of plant pathogenic bacteria and fungi. Eur. J. Plant Path., 101(6): 585-599.

Laemmli UK (1970). Cleavage of structural proteins during the assembly of head of bacteriophage T4. Nature (London), 227: 680685.

Lim SN, Cheung PCK, Ooi VEC, Ang PO (2002). Evaluation of antioxidant activity of extracts from brown seaweed, Sargassum siliquastrum. J. Agric. Food Chem., 50: 3862-3866.

Matsukawa R, Dubinsky Z, Kishimoto E, Masaki K, Masuda Y, Takeuchi T, Chihara M, Yamamoto Y, Niki E, Karube I (1997). A comparison of screening methods for antioxidant activity in seaweeds. J. Appl. Phycol., 9: 29-35.

Mendes RF, Nobre BP, Cardoso MT, Peveira A, Palavra AF (2003). Supercritical carbon dioxide extraction of compounds with pharmaceutical importance from microalgae. Inorgan. Chem. Acta, 356: 328-334.

Mohan IK, Khan M, Shobha JC, Naidu MU, Prayag A, Kuppusamy P, Kutala VK (2006). Protection against cisplatin-induced nephrotoxicity by Spirulina in rats. Cancer Chemther. Pharmacol. 58(6): 802-808.

Murthy KNC, Vanitha A, Rajesha J, Swamy MM, Sowmya PR, Ravishankar GA (2005). In vitro antioxidant activity of carotenoids from Dunaliella salina-a green microalga. Life Sci., 76(12): 13811390.

Nirupama M (2004). Copper induced oxidative stress in the chlorophycean microalga Chlorella Vulgaris response of antioxidant system. J. Plant Physiol., 161(5): 591-597.

Ozdemir G, Karabay NU, Dalay M, Pazarbasi B (2004). Antibacterial activity of volatile component and various extracts of Spirulina 
Platensis. Phytother. Res., 18(9): 754-757.

Piorreck M, Baasch KH, Pohel P (1984). Biomass production, total protein, chlorophylls, lipids and fatty acids of fresh water green and blue-green algae under different nitrogen regimes. Phytochemistry, 23: 207.

Re R, Pellegrini N, Proteggente A, Pannala A, Yang M, Rice-Evans C (1999). Antioxidant activity applying improvedABTS radical cation decolorization assay. Free Radic. Biol. Med., 26: 1231-1237.

Rogel-Yogui CO, Yagui R, Danesi DG, de Carvalha JCM, Sato S (2004). Chloropyll from Spirulina platensis: Cultivation with urea addition by fed batch process. Bioresour. Technol., 92: 133-141.

Reddy MC, Subhashini J, Mahibal SVK, Bhat VB, Reddy PS, Kiranmai G, Madyastha KM, Reddanna P (2003). C-Phycocyanin, a selective cyclooxygenase-2 inhibitor, induces apoptosis in lipopolysaccharidestimulated RAW 264.7 macrophages. Biochem. Biophys. Res. Commun., 304(2): 385-392.

Romano I, Bellitti MR, Nicolaus B, Lama L, Manca MC, Pagrotta E, Gambacorta A (2000). Lipid profile: A useful chemotaxonomic marker for classification of a new cyanobacterium in Spirulina genus. Phytochemistry, 54: 289-294.

Santoso J, Yoshie-Stark Y, Suzuki T (2004). Antioxidant activity of methanol extracts from Indonesian seaweeds in an oil emulsion model. Fisheries Sci., 70(1): 183-188.

Schneider HAW (1966). A simple method of plastid pigments to nschichtchromatographischen separation. J. Chromatogr., 21: 448453.

Shalaby EAA (2004). Chemical and biological studies on Spirulina species. MSc. Thesis, Department of Biochemistry, Faculty of Agriculture, Cairo University.

Shalaby EAA (2008). Biochemical and Biotechnological studies on some marine algae. Ph.D. Thesis, Department of Biochemistry, Faculty of Agriculture, Cairo University, p. 206.

Shanab SMM (2007). Antioxidant and Antibiotic activities of some seaweed (Egyptian Isolates). Int. J. Agric. Biol., 9(2): 220-225.

Shanab SMM, Galal HRM (2007). The interactive effect of salinity and Urea on growth, some related metabolites and antioxidant nzymes of Chlorella sp. and Scenedesmus sp. New Egypt. J. Microbiol., 17: 6475.

Shanmugam M, Mody KH (2000). Heparinoid-active sulphated olysaccharides from marine algae as potential blood anticoagulant agents. Curr. Sci., 79: 1672-1683.

Silva O, Barbose S, Diniz A, Valdeira M, Gomes E (1997). Plant extracts antiviral activity against Herpes Simplex Virus type 1 and African swine fever virus. Int. J. Pharm., 35: 12-16.

Singh SC, Sinha RP, Häder DP (2002). Role of lipids and fatty acids in stress tolerance in cyanobacteria. Acta protozoologica, 41: 297-308.

Smith GD, Doan NT (1999).Cyanobacterial metabolites with bioactivity against photosynthesis in cyanobacteria, algae and higher plants. J. Appl. Phycol., 11: 337-344.

Snedecor GW, Cochran WG (1982). Statistical Methods. The lowa State Univ. Press., Ames., lowa, USA, p. 507.

Sook HH, Young CH, Young KJ, Who SB, Ahand JH, Sue CJ (2004). Inhibitory phlorotannins from the edible brown alga Ecklonia stolonifera on total reactive oxygen species (ROS) generation. Arch. Pharmacol. Res., 27(2): 194-198.
Sudhir PR, Pogoryelov D, Kovaćs L, Garab G, Murtly SDS (2005). The effects of salt stress on photosynthetic electron transport and thylakoid membrane proteins in the cyanobacterium Spirulina Platensis. J. Biochem. Mol. Biol., 38(4): 481-485.

Tedesco MA, Duerr EO (1989). Light, temperature, and nitrogen starvation effects on the total lipid and fatty acid content and composition of Spirulina platensis UTEX 1928. J. Appl. Phycol., 1: 201-209.

USA Pharmacopia (1985). Pharmacopia of United State of America Mack publishing company, p. 482.

Vonshak A, Tomaselli L (2000). Arthrospira (Spirulina) systematics and ecophysiology. In: Whitton B.A., Potts M., Editors. The ecology of cyanobacteria in the Netherlands: Kluwer Academic Publishers.

Witvrouw M, De Clercq E (1997). Sulfated polysaccharides extracted from sea algae as potential antiviral drugs. Gen. Pharmacol., 29: 497511

Xi WY, En LZ, Fen HY, Hong XZ (2003). Inhibition of mouse liver lipid peroxidation by high molecular weight phlorotannis from Sargassum kjellmanianum. J. Appl. Phycol., 15(6): 507-511.

$\mathrm{Xu} \mathrm{X}$, Beardall J, Hallam DN (1998). Modification of fatty acid composition in halophilic antractic microalgae. Phytochemistry, 49: 1249-1252.

Yuan YV, Bone DE, Carrington MF (2005). Antioxidant activity of dulse (Palmaria palmata) extract evaluated in vitro. Food Chem., 91(3): 485-494.

Zarrouk C (1966). Contribution to the study of a cyanophyceae influence of various physical and chemical factors on growth and phototsynthesis Spirulina maxima (Setch. And Gardner) Geithner (Ph.D. Thesis). University of Paris, France, p. 74.

Zhang-Bao Y, Yeguang, L, Yahong G, Zhong Kui L, HongJun H (2004). Selection of haematococcus strains suitable for mass culture. ActaHydrobiologia-Sinica, 28(3): 289-293.

Zhang J, Zhan B, Yao X, Gao Y, Shong J (1995). Antiviral activity of tannin from the pericarp of Punica granatum L. against genital Herpes virus in vitro. Zhongguo Zhong Yao Za Zhi, 20(9): 556-558, 576.

Zhang J, Zhan B, Yao X, Gao Y, Shong J (2007). Evaluation of 28 marine algae from the Qingdao coast for antioxidative capacity, determination of antioxidant efficiency, total phenolic content of fractions and subfractions derived from Symphyocladia latiuscula (Rhodomelaceae). J. Appl. Phycol., 19: 97-108. 